JASEM ISSN 1119-8362

All rights reserved
Full-text Available Online at

www.bioline.org.br/ja
J. Appl. Sci. Environ. Mgt. June, 2006

Vol. 10 (2) 129 - 133

\title{
Effect of Feed Cycling on Specific Growth Rate, Condition Factor, Body Composition And Rna/Dna Ratio Of Cirrhinus mrigala.
}

\author{
*FURHAN IQBAL, MUHAMMAD ALI, KASHIF UMER AND SHABBIR AHMAD RANA \\ Institute of Pure and Applied Biology.Bahauddin Zakariya University, Multan. 60800, Pakistan
}

\begin{abstract}
A randomly selected 60 samples of Cirrhinus mrigala, fingerling sized, were collected from Qadria fish hatchery and farm, Matital road, Multan. Fish were divided into three groups namely, control, 5 and 10 days cyclic feeding group. Specific growth rate $\left(\% \mathrm{~g} \mathrm{day}^{-1}\right)$, condition factor (K), body composition and RNA/DNA ratio of individual specimen and of each group were calculated. It was found that there was highly significant effect of feed cycling on specific growth rate $(\mathrm{P}<0.001)$ and significant effect $(0.01)$ on condition factor of Cirrhinus mrigala. There was a sharp decline in specific growth rate with increase in length of starvation but carp was able to maintain its body constituents i.e., $\%$ water, $\%$ dry body mass, $\%$ ash, $\%$ fat, $\%$ protein and \% organic contents $(\mathrm{P}>0.05)$ suggesting a compensatory growth which was independent of length of starvation. Feed cycling had marked effect $(\mathrm{P}<0.05)$ on RNA/DNA ratio of this carp and a gradual decrease in RNA/DNA ratio was observed with increase in length of starvation. @JASEM
\end{abstract}

In nature, fishes often experience periods of poor food supply, especially during winter months, when food availability may be reduced. Fishes react to an extended period of food shortage by reducing all super-fulvous activity both metabolic and locomotary. When food supply increases again, some fish species show marked growth spurts, a phenomenon termed compensatory growth. The physiological basis of compensatory growth is incompletely understood but starved-reefed animals may increase food intake (become hyperphagic) and/ or improved food conversion efficiency compared with animals reared continuously on liberal feeding regimes (Dempson et al., 2004). In order to separate these two possible mechanisms, it is essential to have information about both food intake and growth responses of individuals following re-alimentation after a period of food restriction (Miglavs and Jobling, 1989a). In order to increase its growth rate an individual must either raise its resource intake or decrease its metabolic costs. Although some workers have reported reduced basal metabolism ( $\mathrm{O}$ ' Connor et al., 2000) and /or increased conversion efficiency (Ali and Wootton, 1998) during recovery, the effect is usually small and is also short lived (Miglavs and Jobling, 1989b). Wright and Hetzal (1985) and Wang and Stickle (1986) considered that tissue concentrations of nucleic acids provide an index of protein synthetic capacity and there is often a correlation between nucleic acid ratios in various tissues, nutritional status and whole body growth rates. It is assumed that measurement of DNA gives an indication of cell numbers and that measurements of RNA can be used as an index of protein synthetic potential (Kikuchi et al., 1986). Change in RNA: DNA ratio can be used as an indicator of change in rate of tissue protein synthesis, provided that protein synthesis per ribosome proceeds at a relatively constant rate. There is increasing evidence that changes in nutritional status can lead to changes in both ribosomal numbers and activity (Lied et al., 1983; Loughna and Goldspink, 1984). So it is perhaps over-simplistic to expect close correlations between tissue RNA concentrations and measured rate of protein synthesis under all experimental conditions. Laboratory studies on the effects of environmental factors on the body composition, RNA: DNA ratio and energy content of fish are needed

to account for the changes of energy content, both under laboratory conditions and in nature and to predict these changes (Dempson et al., 2004).

The present study was initiated to collect the data regarding the effect of feed cycling on specific growth rate, condition factor and RNA/DNA ratio of carp Cirrhinus mrigala.

\section{MATERIALS AND METHODS}

Randomly selected 60 specimen of Cirrhinus mrigala, fingerling sized, were collected from Qadria fish hatchery and farm, Matital road, Multan. Fishes were packed into big plastic bags supplied with aeration and were transported with the help of vehicle to the laboratory of applied fisheries, Institute of Pure and Applied Biology, Bahauddin Zakariya University, Multan. Fishes were kept into already designed and well-managed fiberglass fish aquaria (dimensions of each, $2 \times 2 \times 5 \mathrm{ft}$ ). All the aquaria were supplied with constant aeration by using electric aerators and temperature was maintained by using air coolers throughout the experimental period as experiment was conducted during summer for 90 days. Water depth was maintained and was changed regularly in each aquarium. Three aquaria were used

\footnotetext{
* Corresponding author e-mail: farhanzoologist@hotmail.com

Present address: PKU Labor, University Kinderklinik, AKH, Wahringer Gurtel 18-20, 1090 Wien (Austria)

Fax: 004314063273
} 
namely: control group, 5 days cyclic feeding group and 10 days feeding group. 20 fishes were used for each treatment randomly. After collection fishes were acclimatized to experimental conditions for 10 days before the start of the experiment.

After acclimation initial weight and length were taken. All of live individuals of Cirrhinus mrigala were weighed on an electronic digital balance (Chyo, Japan) to the nearest $0.01 \mathrm{gm}$. Total body length of each individual fish was measured to the nearest of $0.01 \mathrm{~cm}$ using a Perspex measuring tray fitted with a sheet of millimeter ruler. All the measurements were taken from the tip of mouth to the longest caudal fin ray as per method of Abbas (2000). Each fish was tagged with its initial weight and length. At the end of experiment the fishes were left unfed for 24hours to empty their guts and then were taken individually from each aquarium with the help of fine fish net. Final weight and length were recorded for each individual fish following their kill by a strong blow on the head.

For RNA/DNA estimations, 10-20mg (wet weight) samples of white muscle tissue were taken from the dorsal surface below the dorsal fin. Nucleic acids were extracted and quantified using method of Clemmesen $(1988 ; 1993)$ as modified by Steinhart \& Eckmann (1992) and Grant (1996).

All the weights were Log e transformed and specific growth rate was calculated by using the method of
Ali and Wootton (2003). To estimate water contents and dry body mass in each individual fish, the dead pre-weighed and pre-measured fishes were placed as a whole in pre-weighed aluminum foil tray for dry till constant weight in an electric oven (Gallen Kamp, England) at $50-55{ }^{\circ} \mathrm{C}$. To calculate ash contents in each individual fish, $25 \mathrm{mg}$ of sample was taken in a pre weighed, heat resistant china clay crucible and ashed in a Muffle furnace (Sybron thermolyne 1300) for 5-7 hours at $500^{\circ} \mathrm{C}$ and reweighed after cooling. The fat contents were estimated using dry tissue by dry extraction method following the method of Bligh and Dyer (1959), Cui and Wootton (1988) and Salam and Davies (1994). Total protein present in dry mass was be calculated by difference method from the mass of other main constituents i.e., Ash, fat and water (Dawson and Grimm, 1980 and Salam and Davies, 1994). Data was analyzed statistically using analysis of variance procedures by using computer packages MS-Excel and Minitab.

\section{RESULTS AND DISCUSSION}

Effect of feed cycling on specific growth rate (\% g day $^{-1}$ ) and condition factor: There was highly significant effect of feed cycling on specific growth rate $(\mathrm{P}<0.001)$ and significant effect on condition factor $(\mathrm{P}<0.01)$. There was a trend of sharp decrease in specific growth rate and condition factor in 5 and 10 days cyclic feeding groups in comparison with control group (Table 1-2).

Table 1: Comparison of Specific growth rate and Condition factor of Cirrhinus mrigala in relation to different feeding regimes (Mean \pm $\mathrm{SD})$.

\begin{tabular}{cccc}
\hline Parameters & Control & 5 days cyclic feeding & 10 days cyclic feeding \\
\hline Specific growth rate $\left(\%\right.$ g day $\left.^{-1}\right)$ & $0.08554 \pm 0.05361^{\mathrm{a}}$ & $-0.02505 \pm 0.08643^{\mathrm{b}}$ & $-0.07204 \pm 0.08988^{\mathrm{c}}$ \\
Condition factor & $0.71562 \pm 0.04146^{\mathrm{a}}$ & $0.66994 \pm 0.04753^{\mathrm{b}}$ & $0.64874 \pm 0.08942^{\mathrm{b}}$ \\
\hline
\end{tabular}

Effect of feed cycling on body composition: The feed cycling had non-significant effect on all body composition parameters, $(\mathrm{P}>0.05)$ indicating that fish was able to compensate its body composition during re-feeding after starvation cycles and there was no effect of length of starvation on compensatory response (Table 3-4).
Effect of feed cycling on RNA/DNA ratio: There was a highly significant effect of feed cycling on RNA/DNA ratio, $(\mathrm{P}<0.001)$. There was a gradual decline in RNA/DNA ratio of 5 and 10 days cyclic feeding groups in comparison with control group (Table 5-6).

Table 2: ANOVA (analysis of variance) of Specific growth rate and Condition factor in three different feeding treatments of Cirrhinus mrigala.

\begin{tabular}{ccccccc}
\hline S. No. & Parameters & DF & SS & MS & F & P \\
\hline 1 & Specific growth rate $\left(\%\right.$ day $\left.^{-1}\right)$ & 2,48 & 0.21871 & 0.10936 & 17.50 & $0.000^{* * *}$ \\
2 & Condition factor & 2,49 & 0.03987 & 0.01993 & 4.74 & $0.013^{* *}$ \\
\hline$* *$ & = Significant $\mathrm{P}<0.01 ; \quad * * *$ & \multicolumn{1}{l}{ = Highly Significant $\mathrm{P}<0.001$} & &
\end{tabular}


Table 3: Comparison of body composition of Cirrhinus mrigala in relation to different feed cycling regimes (mean \pm SD) .

\begin{tabular}{cccc}
\hline Parameters & Control & $\begin{array}{c}\text { 5 days cyclic } \\
\text { feeding }\end{array}$ & $\begin{array}{c}\text { 10 days cyclic } \\
\text { feeding }\end{array}$ \\
\hline \% Dry body mass & $18.526 \pm 4.956$ & $17.794 \pm 2.783$ & $17.043 \pm 2.474$ \\
\% Water & $81.461 \pm 4.956$ & $82.196 \pm 2.783$ & $82.948 \pm 2.476$ \\
\% Ash, (dry body weight) & $26.900 \pm 5.364$ & $26.807 \pm 8.639$ & $31.612 \pm 6.075$ \\
\% Ash, (wet body weight) & $4.912 \pm 1.246$ & $4.648 \pm 1.439$ & $5.270 \pm 0.695$ \\
\% Fat, (dry body weight) & $19.735 \pm 7.543$ & $20.726 \pm 5.362$ & $17.500 \pm 5.334$ \\
\% Fat, (wet body weight) & $3.372 \pm 1.413$ & $3.731 \pm 1.279$ & $3.065 \pm 1.260$ \\
\% Protein, (dry body weight) & $55.173 \pm 7.757$ & $52.495 \pm 5.689$ & $50.938 \pm 3.634$ \\
\% Protein, (wet body weight) & $10.492 \pm 3.344$ & $9.393 \pm 2.096$ & $8.707 \pm 1.608$ \\
\% Organic contents, (dry body weight) & $73.106 \pm 6.710$ & $73.177 \pm 6.571$ & $68.483 \pm 5.910$ \\
\% Organic contents, (wet body weight) & $13.647 \pm 4.084$ & $13.129 \pm 3.157$ & $11.767 \pm 2.598$ \\
\hline
\end{tabular}

The comparison of three different feeding treatments control, 5 and 10 days cyclic feeding groups of Cirrhinus mrigala showed that feed cycling had marked effect on specific growth rate and condition factor. There was a sharp decrease in specific growth rate with increase in length of starvation. Both 5 and 10 days cyclic feeding groups had negative specific growth rate. There was slight decline in condition factor of 5 and 10 days cyclic feeding groups than that of control. These results indicate that this fish was unable to maintain its specific growth rate and condition factor during re-feeding periods. These results are in contrast to those observed for other fishes. It was observed that Juvenile roach, Rutilus rutilus was able to fully compensate specific growth rate and condition factor when transferred to refeeding after 21 days of starvation and this response was same at different acclimation temperatures at 4,
20, and $27{ }^{0} \mathrm{C}$ (Van Dijk et al., 2005). Wu et al. (2003) found that three spined sticklebacks, Gasterosteus aculcatus showed sufficient growth compensation to recover the growth trajectory shown by control fish daily fed at libitum. This compensation was generated by hyperphagia during the re-feeding periods. This non-compensatory response of Cirrhinus mrigala may be due to the different fish species, climatic adaptations, feeding habits etc. It was seen that Cirrhinus mrigala did not show higher feed intake during re-feeding days, which results in decreased specific growth rate and condition factor in comparison with control group. Cirrhinus mrigala is a detritivorous and warm water fish. Fish did not grow better on artificial feed. Its digestive system and conversion efficiency is different from those fishes showing compensatory growth response (Dempson et al., 2004)

Table 4: ANOVA (analysis of variance) of body composition parameters of Cirrhinus mrigala in relation to different feed cycling regimes.

\begin{tabular}{|c|c|c|c|c|c|c|}
\hline S. No. & Parameters & DF & SS & MS & $\mathrm{F}$ & $\mathrm{P}$ \\
\hline 1 & \% Dry body mass & 2,49 & 19.2 & 9.6 & 0.78 & $0.464^{\mathrm{NS}}$ \\
\hline 2 & $\%$ Water & 2,49 & 19.3 & 9.6 & 0.78 & $0.46^{\mathrm{NS}}$ \\
\hline 3 & \% Ash, (dry body weight) & 2,49 & 273.2 & 136.6 & 2.92 & $0.063^{\mathrm{NS}}$ \\
\hline 4 & \% Ash, (wet body weight) & 2,49 & 3.52 & 1.76 & 1.32 & $0.275^{\mathrm{NS}}$ \\
\hline 5 & \% Fat, (dry body weight) & 2,49 & 99.0 & 49.5 & 1.33 & $0.274^{\mathrm{NS}}$ \\
\hline 6 & \% Fat, (wet body weight) & 2,49 & 3.99 & 1.99 & 1.15 & $0.324^{\mathrm{NS}}$ \\
\hline 7 & \% Protein, (dry body weight) & 2,49 & 157.4 & 78.7 & 2.33 & $0.108^{\mathrm{NS}}$ \\
\hline 8 & \% Protein, (wet body weight) & 2,49 & 27.89 & 13.94 & 2.40 & $0.10^{\mathrm{NS}}$ \\
\hline 9 & \% Organic contents, (dry body weight) & 2,49 & 78.52 & 78.52 & 2.34 & $0.121^{\mathrm{NS}}$ \\
\hline 10 & \% Organic contents, (wet body weight) & 2,49 & 33.6 & 16.8 & 1.55 & $0.223^{\mathrm{NS}}$ \\
\hline
\end{tabular}

It was found that feed cycling had no effect on all body constituents of Cirrhinus mrigala. The \% ash (dry and wet body weight) was higher in 10 days cyclic feeding group than that of control and 5 days cyclic group. Whereas \% dry body mass, \% water, \% fat, \% protein and \% organic contents (dry and wet body weight) were almost same in all feeding groups. These results are in agreement with previous studies carried out on a range of fish species with respect to effects of different feeding regimes on energy contents and body composition. Compensatory growth of warm water species was reported in
Channel Catfish, Ictalurus punctatus (Rafinesque) (Kim and Lovell, 1995), and hybrid sun fish, Lepomis cyanellus Rafinesque $\times$ L. macrochirus Rafinesque (Hayward et al., 1997), Gibel carp but not in Juvenile Arctic charr, Salvelinus alpinus, (Miglavs and Jobling, 1989), three spined sticklebacks, Gasterosteus aculcatus (Ali and Wootton, 1998) Juvenile roach (Van Dijk et al., 2005). The present study confirms the existence of compensatory growth in warm water carp Cirrhinus mrigala. 
Table 5: Comparison of RNA/DNA ratio in three different feeding treatments of Cirrhinus mrigala (mean $\pm \mathrm{SD}$ ).

\begin{tabular}{ccc}
\hline Control & $\begin{array}{c}5 \text { days cyclic } \\
\text { feeding }\end{array}$ & $\begin{array}{c}10 \text { days cyclic } \\
\text { feeding }\end{array}$ \\
\hline $3.8400 \pm 0.0231^{\mathrm{a}}$ & $3.3787 \pm 0.0150^{\mathrm{b}}$ & $3.1900 \pm 0.0153^{\mathrm{c}}$ \\
\hline
\end{tabular}

Table 6: ANOVA (analysis of variance) of RNA/DNA ratio of Cirrhinus mrigala in relation to different feed cycling regimes.

\begin{tabular}{ccccc}
\hline DF & SS & MS & F & P \\
\hline 2,48 & 3.79872 & 1.899362 & 5853.57 & $0.000^{* * *}$ \\
\hline
\end{tabular}

*** = Highly significant, $\mathrm{P}<0.001$

The RNA concentration is a sensitive parameter to determine the growth rate of an organism because it is the organizer of protein synthesis. DNA concentration represents an index of cell numbers since cellular DNA content is insensitive to changes in environmental condition. The ratio of RNA to DNA is, therefore, a more accurate index of metabolic activity than RNA concentration alone because the number does not affect this ratio or size of the cells in a tissue samples (Dortch et al., 1983). In the present study feed cycling had marked effect on RNA/DNA ratio. There was gradual decline in RNA/DNA ratio in 5 and 10 days cyclic groups in comparison with control group. These results are in contrast to those observed for other fish species (Wright and Martin, 1985; Miglavs and Jobling, 1989a,b; Steinhart and Eckmann, 1992). Decreased RNA/ DNA ratio during feed cycling in these fishes suggests that RNA/ DNA parameters were most sensitive to the effect of feed cycling even though the fishes were fed with double quantity of feed to compensate non-feedings days. This difference may be due different fishes, nature of experiment, feeding and environmental adaptations differences. The decreased RNA/DNA ratio could be due to the result of decrease in ribosomal activity i.e. increase in protein synthesized per ribosome in these fishes.

Acknowledgement: Authors are thankful to Director IP \& AB for providing all the necessary facilities during this research work.

\section{REFERENCES}

Abbas, G (2000). Length-weight and Condition factor relationship of Anchovy, (Coilia dussumieria) and Mullet, (Liza carinata) from Bhanbhore backwaters along Sindh coast (Pakistan: Northern Arabian Sea). Pak. J. of Zool..32 (3): 223-228.

Ali, M; Wootton, $\mathrm{R}$ J (1998). Do random fluctuations in the intervals between feeding affect growth rate in Juvenile three spined sticklebacks. J. of Fish Biol. 52: 112-117.

Bligh, E G; Dyer, W J (1959). A rapid method of total lipid extraction and purification. Can. J. of Biochem. and Physio. 37: 911-917.

Caulton, M S; Bursell, E (1977). The relationship between changes in condition and body composition in young Tilapia rendalli (Boulenger). J. of Fish Biol. 11: 143-150.

Clemmesen, C M (1988). A RNA and DNA fluorescence technique to evaluate the nutritional condition of individuals marine fish larvae. Meeresforschung 32:134-143.

Clemmesen, C M (1993). Improvements in the fluorimertic determination of the RNA and DNA content of individual marine fish larvae. Marine Ecol. Prog. Ser. 100: 177-183.

Cui, Y; Wootton, R J (1988). Effects of ration, temperature and body size on the body composition, energy content and condition of the minnow, Phoxinus phoxinus (L.) J. of Fish Biol. 32: 749-764.

Dawson, A S; Grimm, A S (1980). Quantitative seasonal changes in the protein, lipid and energy contents of carass, overies and liver of adult female plaice (Pleuronectes platena L.). J. of Fish Biol. 16: 493.

Dempson, I B; Schwarz, C J; Shears, M; Furey, G (2004). Comparative proximate body composition of Atlantic salmon with emphesis on parr from fluvial and lacustrine habitats. J. Fish Biol. 64: 1257-1271.

Dortch, Q; Roberts, T L.; Clayton, J R; Ahmed, S I (1983). RNA/DNA ratios and DNA concentrations as indicators of growth rate and biomass in planktonic marine organisms.

Marine Ecol. Prog. Ser. 13: 61-71.

Hayward, R S; Noltie, D B; Wang, N (1997). Use of compensatory growth to double hybrid sunfish growth rates. Trans.of the Amer. Fish. Soc. 126: 316-322.

Kikuchi, T; Okamoto, H; Chiku, K; Natori, Y (1986). Effects of Glucose and amino acid depletions on protein synthetic parameters in liver and skeletal muscle of rats during parental nutrition. J. of Nut. and sci. Vit 32: 601-612. 
Kim, M L; Lovell, R T (1995). Effects of restricted feeding regimes on compensatory weight gain and body tissue changes in channel cat fish, Ictalurus punatatus in ponds. Aquaculture 135: 285-293.

Lied, E.; Rosenlund, G; Lund, B; Von D D A (1983). Effect of starvation and re-feeding on in vitro protein synthesis in white trunk muscle of Atlantic cod (Gadus morhua). Comp. Biochem. and physio. 76B: 777-781.

Loughna, P T; Goldspink, G (1984). The effects of starvation upon protein turnover on red and white myotomal muscle of rainbow trout, Salmo gairdneri Richardson. J. of Fish Biol. 25: 223230.

Miglavs, I; Jobling, M (1989a). Effects of feeding regime on food consumption, growth rates and tissue nucleic acids in Juvenile Arctic charr, Salvelinus alpinus, with particular reference to compensatory growth. J. of Fish Biol. 34: 947957.

Miglavs, I; Jobling, M (1989b). The effects of feeding regime on proximate body composition and patterns of energy deposition in Juvenile Arctic charr, Salvelinus alpinus. J. of Fish Biol. 35: 1-11.

O,Connor, K I; Taylor, A C.; Metcalfe, N B (2000). The stability of standard metabolic rate during a period of food deprivation in Juvenile Atlantic salmon. J. of Fish Biol. 57: 41-51.
Salam, A; Davies, P M C (1994). Body composition of Northern Pike, (Esox lucius L.) in relation to body size and condition factor. Fish. Res. 19:199-204.

Steinhart, M; Eckmann, R (1992). Evaluating the nutritional condition of white fish (Coregonus spp.) larvae by the RNA/DNA ratio. J. of Fish Biol. 40: 791-799.

Van Dijk, P L M; Hardewig, I; Holker, F (2005). Energy reserves during food deprivation and compensatory growth in juvenile roach, Rutilus rutilus: the importance of season and temperature. J. of Fish Biol. 66: 167-181.

Wright, D A; Hetzel, E W (1985). Use of RNA: DNA ratios as an indicator of nutritional stress in the American oyster, Crassostrea virginica. Marine Ecol. Prog. Ser. 25: 199-206.

Wu, L.; Xie, S; Cui, Y; Wootton, R J (2003). Effect of cycles of feed deprivation on growth and food consumption of immature three spined sticklebacks and European minnows. J. of Fish Biol. 62: 184-194.

Wright, D A; Martin, F D (1985). The effect of starvation on RNA: DNA ratios and growth of larval striped bass, Morone Sanatilis. J. of Fish Biol. 27: 479-485.

Wang, S Y; Stickle, W B (1986). Changes in nucleic acid concentration with starvation in the bluecrab, Callinectes sapidus Rathbun. J. of crus. Biol. 6: 49-56. 